\title{
Ayurveda - A Powerful Healing Tool for COVID-19
}

\section{Tarnam YA*}

Department of Biotechnology, Bharathidasan University, India

*Corresponding author: Dr. Y. Arsia Tarnam, Assistant Professor, PG and Research Department of Biotechnology, Jamal Mohamed College (Autonomous), Affiliated to Bharathidasan University, Tiruchirappalli-620020, Tamilnadu, India, Email: arsia.sherif@gmail.com

\section{Mini Review \\ Volume 5 Issue 1}

Received Date: December 20, 2020

Published Date: January 26, 2021

DOI: $10.23880 /$ jonam-16000292

\section{Abstract}

Ayurveda is a plant based science that helps to maintain healthy and happy life. As the globe is suffering from COVID-19 outbreak, it's become essential to enhance the body's immune system to maintain healthy life. The daily regimes (Dinacharya) and seasonal regimes (Ritucharya) plays an important role in this. In was reported that the use of four ayurveda interventions such as ayush kwatha, sanshamanivati, fifatrol tablets and laxmivilasa rasa helps to improve COVID-19 condition within six days of treatment. It was inferred with several case studies that Ayurveda has the potential to improve COVID-19 conditions.

Keywords: Ayurveda; Immunity; COVID-19; Yoga; Herbs and Immunity

\section{Introduction}

The global pandemic COVID-19 disease also known as the severe acute respiratory syndrome coronavirus 2 (SARS-CoV-2) by the International Committee on Taxonomy of Viruses (ICTV) and belongs to the Coronaviridae family, Orthocoronavirinae subfamily [1] order Nidovirales and subdivided into four genera, Alphacoronavirus, Betacoronavirus, Gammacoronavirus and Deltacoronavirus. Globally and in India, the coronavirus disease was reported to be $74.9 \mathrm{M}$ and $9.96 \mathrm{M}$ as of December, 2020 respectively. Coronaviruses are $65-125 \mathrm{~nm}$ in diameter and possess crown like spikes on the outer surface that is due to $\mathrm{S}$ proteins (1,160 amino acids) present as a trimer on the virion surface and hence it is named as coronavirus [2]. The genome of coronavirus is an enveloped, unsegmented, positive sense, single stranded RNA size ranges from 26 to $32 \mathrm{Kbs}$ in length $[2,3]$. The genome of SARS-CoV-2 is 29,891 bp long and contains $38 \%$ of $\mathrm{G}+\mathrm{C}$ content [2]. Out of four structural proteins (spike (S), envelope (E), membrane (M), and nucleocapsid $(\mathrm{N})$ ), the spike glycoprotein plays an important role in attachment with the host cell membrane thereby causing virus infection transmitting through respiratory droplets. The incubation period of this virus is estimated to range between 2-14 days [4]. The clinical symptoms of COVID-19 are fever, dry cough, fatigue, dyspnoea, with mild headache, nasal congestion, runny nose, sore throat, vomiting and diarrhoea [1-3].

Reverse transcriptase quantitative PCR which is nucleic acid detection method is commonly used in detection of COVID-19 [2]. In GenBank the complete SARS-CoV-2 genome sequence is available. CRISPR-based SHERLOCK technique is also used for the detecting SARS-CoV-2. Antiviral therapy that are available and considered to treat COVID-19 are Interferon-alpha, lopinavir/ritonavir, ribavirin, chloroquine, arbidol and remdesivir. The cellular therapy using NK cells and mesenchymal stem cells are used to treat and prevent COVID-19. In the Immunotherapy, the convalescent plasma therapy, monoclonal antibodies, Chinese medicine [5] also plays a key role in treating COVID-19 pneumonia [1].

Currently the possible ways to prevent this disease are maintaining respiratory hygiene, personal hygiene and physical distancing. The average value of COVID-19 virus reproduction number is 3.6, which is highly contagious. Several steps that are being taken to reduce the spread of infection are increased physical distancing [6], close down factories, offices, educational institution, avoid mass gathering of people and in exceptional cases, to operate with 


\section{Journal of Natural \& Ayurvedic Medicine}

minimum capacity [7].

Currently there are no vaccines available for treatment of COVID-19. Researchers all over the world are working to find potential treatment options. Until then, to boost the immunity among all, Ministry of AYUSH, Government of India has issued guidelines [8]. Ayurveda is a traditional plant based science, which is originated in India 3000 years ago and can be used in several situations such as to enhance immunity, immunomodulators, local and systemic interventions. Especially Rasayana are used to boost immune system thereby helps to prevent and treat the pandemic diseases $[8,9]$. The Ayurveda medicine has been reported to be safe, efficacy, easily available and administration, affordability. People are divided into four groups (unexposed asymptomatic group, exposed asymptomatic group, with mild COVID-19 symptoms and with moderate to severe COVID-19 symptoms) based on Ayurveda intervention during COVID-19 [5,10]. It also recommended that the formulations of Tribhuvankirti Rasa, Paripathadi Kwath, Samirapannaga Rasa, Kalingadi Kashaya, Mallaasindoor, Lakshmivilas Rasa and Vyaghri Haritaki Avaleha for curing COVID-19 but further study is recommended for supportive scientific evidence. Yoga such as Bhastrika, Ujjayi and Anulom-Vilom; Suryanamaskar, Halasana, Chakrasana are also can be done to increase total lung capacity and to reduce mucus from respiratory system respectively. Herbs that are proven to have immunomodulatory activity are Hibiscus rosasinensis, Cleome gynandra, Tinospora cordifolia, Balanite roxburghi, Aloe vera, Picrorhiza scrophulariiflora, Ocimum sanctum, Bauhinia variegate, Citurs aurantifolia, Allium sativum, Andrographis paniculata. Ayurveda practices such as Hasta-pada Dhavan, Aushadhi youka jala snana, Abhyanga, Kavala-Gandusha, Nasya, and Trividha Kukshi Ahara are also recommended for preventing COVID-19 [9] [11]. From this it is clear that Ayurveda has the potential to cure and prevent COVID-19 but further establishment and scientific validation is needed to facilitate individually or synergistic effects between traditional and modern medicine [11]

\section{References}

1. Li H, Liu S, Yu X, Tang S, Tang C (2020) Coronavirus disease 2019 (COVID-19): current status and future perspectives. Int J Antimicrob Agents 55(5): 1-9.

2. Dhama K, Khan S, Tiwari R, Sircar S, Bhat S, et al. (2020) Coronavirus Disease 2019-COVID-19 Kuldeep. Clin Microbiol Rev 33(4): 1-48.

3. Adnan M, Khan S, Kazmi A, Bashir N, Siddique R (2020) COVID-19 infection : Origin , transmission , and characteristics of human coronaviruses. J Adv Res 24: 91-98.

4. Khanna RC, Cicinelli MV, Gilbert SS, Honavar SG, Murthy GVS (2020) COVID - 19 pandemic : Lessons learned and future directions. Indian J Ophthalmol 68(5): 703-710.

5. Rastogi S, Narayan D, Harsh R (2020) COVID-19 pandemic: A pragmatic plan for ayurveda intervention. J Ayurveda Integr Med.

6. Kakar A (2020) COVID-19 in India. J R Soc Med 113(6): 232-233.

7. Bandyopadhyay S (2020) Coronavirus Disease 2019 (COVID-19): we shall overcome. Clean Technol Environ Policy 22(3): 545-546.

8. Golechha M (2020) Time to realise the true potential of Ayurveda against COVID-19. Brain Behav Immun 87: 130-131.

9. Rajput S (2020) Evolution, Ayurveda, immunity, and preventive aspects for emerging infectious diseases such as COVID-19. Int J Res Pharm Sci 11(1): 86-93.

10. Nc S, Devesh S (2020) Ayurveda and COVID-19. J Nat Ayurvedic Med 4(3): 1-4.

11. Rajkumar RP (2020) Ayurveda and COVID-19: Where psychoneuroimmunology and the meaning response meet. Brain Behav Immun J 87: 8-9. 